УДК 372.2

DOI 10.23951/2307-6127-2020-2-220-232

\title{
ОСОБЕННОСТИ ИСПОЛЬЗОВАНИЯ МОДУЛЬНОГО ПОДХОДА ДЛЯ РАЗВИТИЯ РЕЧЕВОГО ТВОРЧЕСТВА У СТАРШИХ ДОШКОЛЬНИКОВ В УСЛОВИЯХ ДЕТСКОГО САДА
}

\section{О. А. Кривоногова}

\author{
Детская организация раннего развития «Ладушки», Томск
}

Преобразования, связанные с реформированием дошкольного образования в России на рубеже XIX-XXI вв., определили содержание понятия «речевое творчество» и теоретико-методологических подходов к развитию речи и речевого творчества у детей. В конце XX в. понятие «речевое творчество» впервые связывается с художественно-творческой активностью ребенка; складываются разные научные представления о развитии речевого творчества у детей. Организация процесса развития речевого творчества у предшкольников в соответствии с идеологией нового стандарта дошкольного образования требует целостного представления о педагогических способах формирования детской художественно-творческой активности средствами сказки. В связи с этим актуальным является использование модульного подхода как инновационной организационно-педагогической основы развития речевого творчества у детей в контексте концептуальных положений нормативного документа. В основе проектирования модулей лежит закономерная связь репродуктивного, продуктивного и творческого этапов формирования речетворческой деятельности у старших дошкольников, которые отражают логику становления детских видов деятельности на протяжении дошкольного детства и сопровождаются разными типами совместной деятельности взрослого и детей с ориентацией на развивающие и гуманистические отношения участников взаимодействия. Образовательные ресурсы модулей ориентированы на раскрытие и обогащение субъективного опыта деятельности у детей с учетом их интересов и возможностей. Эффективность реализации модульной модели развития детского речевого творчества в детском саду подтверждается успешным формированием у детей предпосылок к учебной деятельности.

Ключевые слова: речевое творчество, старшие дошкольники, модульный подход, модульная модель, предпосылки универсальных учебных действий.

Преобразования, связанные с реформированием дошкольного образования в России на рубеже XIX-XXI вв., определили содержание сущности понятия «речевое творчество» дошкольников и теоретико-методологических подходов к развитию речи и речевого творчества у детей. В конце XX в. понятие «речевое творчество» впервые связывается с художественно-творческой активностью ребенка; складываются разные научные представления о развитии речевого творчества у детей. Исследователями было установлено, что творческое рассказывание на основе сказки - наиболее привлекательный вид художественно-речевой деятельности для старших дошкольников $[1,2]$. Организация процесса развития речевого творчества у предшкольников в соответствии с идеологией нового стандарта дошкольного образования требует целостного представления о педагогических способах формирования детской художественно-творческой активности средствами сказки [3]. В связи с этим актуальным является использование модульного подхода для развития речевого творчества у детей в контексте концептуальных положений нормативного документа. Принципы модульности и гибкости как одни из базовых принципов модульного подхода имеют следую- 
щее толкование в педагогических исследованиях. Модуль является законченным блоком единой модульной программы. Каждый субъект может освоить модуль или модули в соответствии со своими интересами и возможностями. Модульная программа обеспечивает раскрытие потенциальных способностей всех субъектов за счет вариативности целей, содержания, методического руководства, системы контроля и оценок в модулях [4]. Несмотря на то, что модульный подход недостаточно изучен и применим в теории и практике дошкольного образования, он выступает как инновационно-педагогический способ организации процесса развития речевого творчества у старших дошкольников в современном детском саду. Принципы модульного подхода (модульности и гибкости) позволяют реализовать принципы культурно-исторического, личностно ориентированного и системно-деятельностного подходов (деятельностного, развивающего, гуманистического сотрудничества взрослого и детей, преемственности между дошкольным и начальным общим образованием). При этом культурно-исторический и личностно ориентированный подходы составляют теоретическую, а системно-деятельностный и модульный подходы - практическую основу процесса развития речевого творчества у старших дошкольников.

В основе проектирования модулей развития речевого творчества у детей лежит закономерная связь репродуктивного, продуктивного и творческого этапов формирования речетворческой деятельности старших дошкольников. На репродуктивном этапе у детей формируются инвариативные представления о художественном образе и способы действий, направленные на воспроизведение сказки. На продуктивном этапе у дошкольников складываются вариативные представления о художественном образе и способы действий, ориентированные на преобразование и сочинение сказки. На творческом этапе у старших дошкольников появляется возможность проявить независимость и оригинальность в реализации освоенных ими способов действий. Этапы развития речевого творчества детей отражают логику становления детских видов деятельности (восприятия художественной литературы и фольклора, речевой; коммуникативной, игровой, познавательно-исследовательской - сквозных механизмов развития речетворческой деятельности ребенка) на протяжении дошкольного детства и сопровождаются разными типами совместной деятельности $(С Д)$ взрослого и детей с ориентацией на развивающие и гуманистические (открытые) отношения участников взаимодействия. В инструктивно-исполнительском типе совместной деятельности реализуются нормативные связи, квазиэвристическом типе совместной деятельности - ценностные связи, развивающем типе совместной деятельности - личностные связи участников взаимодействия [5-7]. Данные положения уточняют названия и отличительные черты модулей (табл. 1).

Типовая структура модуля, представленная критериально-диагностическим, целесодержательным и технологическим компонентами, отражает особенности взаимодействия взрослого и детей в речетворческом процессе с учетом специфики дошкольного образования: определяет особый характер организации процедуры оценки и процесса развития речевого творчества у старших дошкольников. Взаимодействие взрослого и детей должно начинаться с анализа особенностей развития речевого творчества у старших дошкольников. Каждый последующий шаг в планировании образовательной работы педагог осуществляет, ориентируясь на предыдущие результаты развития речевого творчества детей.

Критериально-диагностический компонент модулей включает педагогический мониторинг, который нацелен на определение особенностей развития речевого творчества у детей по показателям сформированности интеллектуальных, регулятивных, коммуникативных и личностных действий в рамках соответствующих критериев (табл. 2). Показатели развития речевого творчества детей - основные характеристики детских видов деятельности, которые складываются в дошкольном возрасте и могут проявляться у старших дошкольников 
как возможные результаты развития в разных типах СД со взрослым и сверстниками. Представление о высоком разбросе вариантов развития ребенка в рамках одной возрастной группы задает требования к игровым ситуациям как средствам педагогического мониторинга.

Таблица 1

Основания для проектирования модулей развития речевого творчества детей

\begin{tabular}{|c|c|c|c|}
\hline Модуль & Инваритивный & Вариативный & Творческий \\
\hline Этап & Репродуктивный & Продуктивный & Творческий \\
\hline \multirow{3}{*}{ Тип СД } & Инструктивно-исполнитель- & Квазиэвристический & Развивающийся \\
& ский (нормативные связи & (ценностные связи & (личностные связи \\
& взрослого и детей) & взрослого и детей) & взрослого и детей) \\
\hline
\end{tabular}

Таблица 2

Критериально-диагностический компонент модулей развития речевого творчества детей

\begin{tabular}{|c|c|c|}
\hline $\begin{array}{c}\text { Модуль / } \\
\text { тип СД }\end{array}$ & $\begin{array}{l}\text { Критерии развития } \\
\text { речевого творчества }\end{array}$ & Показатели развития речевого творчества \\
\hline \multirow{4}{*}{$\begin{array}{l}\text { Инвариа- } \\
\text { тивный / } \\
\text { инструк- } \\
\text { тивно-ис- } \\
\text { полнитель- } \\
\text { ский }\end{array}$} & Интеллектуальный & $\begin{array}{l}\text { Строит модель классической сказки, связно, выразительно пересказы- } \\
\text { вает ее сюжет с опорой на модель; выражает общепринятое аргументи- } \\
\text { рованное отношение к поступкам героя, ориентируясь на модель/ } \\
\text { конвенциональный символ }\end{array}$ \\
\hline & Коммуникативный & $\begin{array}{l}\text { Налаживает деловое сотрудничество со взрослым и сверстниками по } \\
\text { поводу знакомой сказки, следует принятым нормам поведения }\end{array}$ \\
\hline & Регулятивный & $\begin{array}{l}\text { Сохраняет цель деятельность, исправляет ошибки, соблюдает очеред- } \\
\text { ность в осуществлении действий }\end{array}$ \\
\hline & Личностный & Выбирает наглядные и вербальные средства \\
\hline \multirow{4}{*}{$\begin{array}{l}\text { Вариатив- } \\
\text { ный / } \\
\text { квазиэври- } \\
\text { стический }\end{array}$} & Интеллектуальный & $\begin{array}{l}\text { Экспериментирует с моделью литературного произведения, придумы- } \\
\text { вает отдельные события к классической сказке или сочиняет ориги- } \\
\text { нальную сказку на заданную событийную/смысловую тему, связно и } \\
\text { выразительно рассказывает сказку с опорой на модель; выражает } \\
\text { собственное аргументированное отношение к поступкам героя, } \\
\text { ориентируясь на конвенциональный/многоплановый символ }\end{array}$ \\
\hline & Коммуникативный & $\begin{array}{l}\text { Налаживает познавательные контакты со взрослым, выходящие за рамки } \\
\text { конкретной ситуации, внеситуативное деловое сотрудничество и познава- } \\
\text { тельные контакты с ровесниками, выполняет правила и нормы поведения }\end{array}$ \\
\hline & Регулятивный & $\begin{array}{l}\text { Планирует деятельность, стремится довести начатое дело до конца, получить } \\
\text { творческий результат, соблюдает очередность в осуществлении действий }\end{array}$ \\
\hline & Личностный & $\begin{array}{l}\text { Выбирает наглядные, вербальные средства, творческие приемы, } \\
\text { способы конструктивного общения в кооперативно-соревновательном } \\
\text { взаимодействии со сверстниками, выражает свои мысли и чувства }\end{array}$ \\
\hline \multirow{4}{*}{$\begin{array}{l}\text { Творче- } \\
\text { ский / } \\
\text { развиваю- } \\
\text { щий }\end{array}$} & Интеллектуальный & $\begin{array}{l}\text { Сочиняет и связно, выразительно рассказывает сказку по замыслу, } \\
\text { раскрывая ее содержание/идею, с опорой на модель }\end{array}$ \\
\hline & Коммуникативный & $\begin{array}{l}\text { Налаживает личностные контакты со взрослым, выходящие за рамки } \\
\text { конкретной ситуации, внеситуативное деловое сотрудничество, } \\
\text { познавательные и личностные контакты с ровесниками в соответствии } \\
\text { с правилами и нормами поведения }\end{array}$ \\
\hline & Регулятивный & $\begin{array}{l}\text { Планирует и контролирует деятельность в соответствии с поставлен- } \\
\text { ной задачей }\end{array}$ \\
\hline & Личностный & $\begin{array}{l}\text { Выбирает средства для реализации действий, замысел сказки и } \\
\text { творческие приемы, способы коммуникативных действий, участников } \\
\text { совместной деятельности и общения, выражает свои мысли и чувства }\end{array}$ \\
\hline
\end{tabular}

Во-первых, последовательная реализация игровых ситуаций позволяет обнаружить все показатели развития речевого творчества у детей как вероятностные достижения старших дошкольников. Во-вторых, игровые ситуации построены таким образом, что появляется возможность наблюдать показатели развития речевого творчества у детей неоднократно. 
В этом случае повышается объективность оценки особенностей речетворческой деятельности у ребенка. В-третьих, поскольку игровые ситуации предполагают взаимодействие взрослых и детей, то они выявляют не только продукты речевого творчества ребенка, но и особенности его деятельности и поведения в речетворческом процессе. В-четвертых, игровые ситуации не требуют дополнительного времени в их организации, потому что они интегрированы в процесс развития речевого творчества у детей. Осваивая действия в одних игровых ситуациях, старшие дошкольники могут продемонстрировать эти действия в других игровых ситуациях по отражению или созданию художественного образа. В этом процессе каждый ребенок овладевает культурой выбора и соорганизации различных образовательных предложений [8]. Поэтому данная система оценивания подчеркивает образовательный потенциал модулей развития речевого творчества дошкольников.

Результаты развития речевого творчества у детей, полученные в ходе педагогического мониторинга, фиксируются с помощью вербальной двухуровневой шкалы оценки сформированности действий ребенка: сформированы или не сформированы действия. Выбор данной шкалы объясняется представлениями о гибкости и пластичности развития дошкольников. Так, если дети сегодня не показывают те или иные действия, то завтра они могут быть сформированы в СД со взрослым и более опытными ровесниками. В этом смысле оценка уровня развития ребенка в балльной системе, направленная на установление соответствия этого уровня некоторому среднему, характерному для детей данной возрастной группы, противоречит представлениям об особенностях развития дошкольников $[3,5,9]$.

На основе результатов педагогического мониторинга взрослый осуществляет индивидуализацию развивающих воздействий для каждого ребенка и оптимизацию работу с группой детей за счет целесодержательного и технологического компонентов модулей развития речевого творчества у старших дошкольников (табл. 3-5).

Целесодержательный компонент модулей включает содержание детских видов деятельности, которое меняется в разных типах СД взрослого и детей, нацелено на поддержку инициативности и активности старших дошкольников и обеспечивает актуализацию личностных представлений ребенка с последующим их воплощением в собственной речетворческой деятельности.

Технологический компонент модулей представляет собой совокупность методов, способов, форм и средств (элементов развивающей предметно-пространственной среды) развития речевого творчества у детей, способствующих раскрытию субъективного опыта ребенка в разных типах СД со взрослым, сверстниками, разыгрывающих роли от «режиссера» до партнера.

1. Методы и способы развития речевого творчества детей. Объяснительно-иллюстративный, репродуктивный, проблемный, частично-поисковый и исследовательский методы развития речевого творчества старших дошкольников выстраиваются по характеру познавательно-исследовательской деятельности детей в направлении обогащения детского опыта.

Ролевой диалог по мотивам классической сказки, диалог на познавательные темы и по решению проблем, ролевой диалог реальных персонажей на фоне общего сюжета, реальный организационно-деловой диалог, диалог на личностные темы - способы расширения детско-взрослой и детской совместности в речетворческом процессе $[10,11]$.

Деятельность ребенка приобретает характер самодеятельности при освоении и практическом применении дошкольником многообразного практического опыта в условиях игры [12].

2. Развивающая речевое творчество предметно-пространственная среда должна быть насыщенной (разнообразие наглядных и вербальных средств, обслуживающих детскую де- 
ятельность); полифункциональной (возможность использовать наглядные и вербальные средства в разных видах детской деятельности); вариативной, доступной и трансформируемой (наглядные и вербальные средства размещаются в различных игровых пространствах, доступны для свободного выбора ребенком в реализации им сказочного замысла и его интерпретации, меняются в зависимости от образовательной ситуации, возможностей и интересов детей) [13].

3. Формы совместной деятельности взрослого и детей и самостоятельная деятельность старших дошкольников. Речетворческая деятельность осваивается ребенком во взаимодействии со взрослым и ровесниками, затем - со сверстниками и только потом становится его самодеятельностью.

Таблица 3

Целесодержательный и технологический компоненты инвариативного модуля развития речевого творчества детей

\begin{tabular}{|c|c|c|}
\hline $\begin{array}{c}\text { Модуль / } \\
\text { тип СД }\end{array}$ & $\begin{array}{c}\text { Технологическое сопровождение разви } \\
\text { речевого творчества детей }\end{array}$ & $\begin{array}{c}\text { Целесодержательный аспект развития речевого } \\
\text { творчества детей }\end{array}$ \\
\hline \multirow{4}{*}{$\begin{array}{l}\text { Инвариа- } \\
\text { тивный / } \\
\text { инструк- } \\
\text { тивно- } \\
\text { исполни- } \\
\text { тельский }\end{array}$} & $\begin{array}{l}\text { Методы: объяснительно-иллюстративный и } \\
\text { репродуктивный. } \\
\text { Способы: дидактическая игра, сюжетно-роле- } \\
\text { вая игра (ролевой диалог по мотивам класси- } \\
\text { ческой сказки со взрослым, игрушкой, сверст- } \\
\text { никами). } \\
\text { Диалог на познавательные темы (по содержа- } \\
\text { нию классической сказки) }\end{array}$ & $\begin{array}{l}\text { Формирование инвариативных представлений о } \\
\text { художественном образе (сюжете и герое сказки); } \\
\text { интеллектуальных действий (моделирование, } \\
\text { пересказывание сказки, выражение общеприня- } \\
\text { того отношения к персонажу) }\end{array}$ \\
\hline & $\begin{array}{l}\text { Средства: наглядные (демонстрационный и } \\
\text { раздаточный материал (изображения культур- } \\
\text { ного контекста), игрушки, ролевые атрибуты) } \\
\text { и вербальные (тексты классических сказок) }\end{array}$ & $\begin{array}{l}\text { Формирование коммуникативных действий: } \\
\text { налаживание делового сотрудничества со } \\
\text { взрослым и сверстниками по поводу классиче- } \\
\text { ской сказки; следование принятым нормам } \\
\text { поведения }\end{array}$ \\
\hline & \multirow{2}{*}{$\begin{array}{l}\text { Формы совместной деятельности взрослого и } \\
\text { детей: групповая, подгрупповая; индивидуаль- } \\
\text { ная с ребенком; самостоятельная парная, } \\
\text { подгрупповая деятельность детей }\end{array}$} & $\begin{array}{l}\text { Формирование регулятивных действий: сохране- } \\
\text { ние цели деятельности; исправление ошибок; } \\
\text { соблюдение очередности в осуществлении } \\
\text { действий }\end{array}$ \\
\hline & & $\begin{array}{l}\text { Формирование личностных действий: выбор } \\
\text { наглядных и вербальных средств }\end{array}$ \\
\hline
\end{tabular}

Освоение инвариативного модуля развития речевого творчества детей характеризуется инструктивно-исполнительским типом СД взрослого и старших дошкольников.

В дидактической и сюжетно-ролевой игре взрослый предъявляет детям правила и образцы деятельностей, которые они осваивают и воспроизводят под контролем педагога и сверстников, т. е. сначала организуется их совместная деятельность. Позже дети играют самостоятельно. «Самостоятельная деятельность детей»- выражение условное, так как она также осуществляется под руководством взрослого и ровесников.

Совместная групповая и подгрупповая деятельность взрослого и детей протекает с применением демонстрационного материала, который включает фланалеграф - большое панно из ковролина, временно-пространственную модель с карманами для вкладывания изображений событий сказки, альбом со знаковым (сюжетными картинками по мотивам классической сказки) и символическим (конвенциональными символами) материалом. В совместной деятельности взрослого и ребенка, самостоятельной деятельности детей используется раздаточный материал (уменьшенная копия демонстрационного материала).

Деловые и познавательные контакты взрослого и детей (ролевой диалог сказочных персонажей, общение на тему сказки) не выходят за рамки содержания литературного про- 
Кривоногова О. А. Особенности использования модульного подхода...

изведения и тех средств, с помощью которых воссоздается художественный образ. Проявления активности детей отмечаются и поощряются взрослым.

Формирование инвариативных представлений о сказке и способов действий по ее воспроизведению необходимо для освоения детьми вариативного модуля развития речевого творчества.

Освоение вариативного модуля развития речевого творчества детей характеризуется квазиэвристическим типом СД взрослого и детей.

В игре-небылице, сюжетно-ролевой игре и игре-фантазировании взрослый создает различные проблемные ситуации, которые вызывают удивление у детей, потому что дошкольники уже не могут решить вроде бы знакомую задачу привычным способом. После осознания детьми проблемы (например, как придумать новое событие (события) к классической сказке? или как распределить очередность игровых действий?) взрослый организует совместное обсуждение, в котором выдвигаются разные варианты, выбирается и проверяется наиболее подходящий (социально-приемлемый) способ решения проблемы. В таких играх взрослый также занимает позицию активного участника и в случае необходимости оказывает помощь детям: задает вспомогательные и наводящие вопросы, предлагает варианты, напоминает о правилах игры. При этом он создает условия, в которых дошкольники занимают позицию «вопрошающих» не только в совместной с ним деятельности, но и позже в совместной деятельности с ровесниками. Поэтому у детей появляется возможность продемонстрировать перед сверстниками свои способности, показать себя мастером рассказа.

Проблемная ситуация направлена на частичный поиск информации и преодоление стереотипов деятельности. Теперь по-другому создается, интерпретируется и воспринимается художественный образ. Познавательные контакты детей и взрослого выходят за рамки конкретной ситуации. Они используют по своему усмотрению иной, не относящийся к классической сказке, знаково-вербальный (с лишними, противоречивыми, недостающими данными, реальными фактами, сюжетами и героями фольклорных историй, современных мультфильмов; потешки, считалки) материал, ролевые атрибуты персонажей-людей. Деловое сотрудничество детей и сверстников оказывается внеситуативным. Дошкольники договариваются об очередности действий до начала игры, по ходу ее реализации планируют деятельность сверстников высказываниями, которые являются регулятором игрового взаимодействия.

В обмене мнениями по поводу поступков героев используются конвенциональные и многоплановые символы, дающие свободу в выражении отношения к действиям персонажей сказки. Выбор символов необходим для обсуждения хода и результатов совместной и самостоятельной деятельности участников игры. Взрослый показывает детям рост их достижений, вовлекает дошкольников в оценку своих возможностей. В совместном (групповом и подгрупповом) взаимодействии взрослого и детей применяется демонстрационный и раздаточный материал. Важно, чтобы раздаточный материал был всегда «под рукой» для комбинирования сказки в совместной деятельности детей и индивидуальной работе ребенка.

Формирование вариативных представлений о художественном образе и способов действий по созданию оригинальной сказки целесообразно для освоения дошкольниками творческого модуля развития речевого творчества.

Освоение детьми творческого модуля развития речевого творчества сопровождается развивающим типом СД взрослого и старших дошкольников.

Дети и взрослый рассказывают друг другу о реальных событиях, произошедших с ними, делятся планами, желаниями, секретами. Сказочные замыслы становятся целенаправленными, так как в них отражаются личностно значимые темы. Игра принимает фор- 
му самодеятельности. Дети могут из дружеских побуждений научить товарища тому, чем сами хорошо владеют. Взрослый не вмешивается в детскую игру, но может быть принят детьми в качестве ее участника. Взрослый и дети предлагают свои варианты игр. Освоение этого модуля предполагает достаточно выраженные формы развития произвольности поведения у детей, но если деятельность интересна ребенку, то проблем с ее реализацией, как правило, у него не возникает. Дети приобретают бо́льшую свободу, становятся полноправными субъектами деятельности.

Таблица 4

Целесодержательный и технологический компоненты вариативного модуля развития речевого творчества детей

\begin{tabular}{|c|c|c|}
\hline $\begin{array}{c}\text { Модуль / } \\
\text { тип СД }\end{array}$ & $\begin{array}{c}\text { Технологическое сопровождение развития } \\
\text { речевого творчества детей }\end{array}$ & $\begin{array}{c}\text { Целе-содержательный аспект развития речевого } \\
\text { творчества детей }\end{array}$ \\
\hline \multirow{3}{*}{$\begin{array}{l}\text { Вариатив- } \\
\text { ный / } \\
\text { квазиэв- } \\
\text { ристиче- } \\
\text { ский }\end{array}$} & $\begin{array}{l}\text { Методы: проблемная ситуация (анализ } \\
\text { и сравнение), частично-поисковый. } \\
\text { Способы: игра-небылица, игра-фантазирова- } \\
\text { ние, сюжетно-ролевая игра (диалог на позна- } \\
\text { вательные темы, по решению проблем, } \\
\text { ролевой диалог реальных персонажей на фоне } \\
\text { сюжета, реальный организационно-деловой } \\
\text { диалог) }\end{array}$ & $\begin{array}{l}\text { Формирование вариативных представлений о } \\
\text { художественном образе (сюжете и герое сказки); } \\
\text { интеллектуальных действий (экспериментирова- } \\
\text { ние, придумывание отдельных событий к } \\
\text { классической сказке, сочинение оригинальной } \\
\text { сказки на заданную событийную/смысловую } \\
\text { тему, рассказывание сказки, выражение собст- } \\
\text { венного отношения к персонажу) }\end{array}$ \\
\hline & $\begin{array}{l}\text { Средства: наглядные (демонстрационный и } \\
\text { раздаточный материал (вариативные изобра- } \\
\text { жения), ролевые атрибуты); вербальные } \\
\text { (тексты классических сказок, современных } \\
\text { мультфильмов; небылиц, реальных историй, } \\
\text { малых фольклорных жанров) }\end{array}$ & $\begin{array}{l}\text { Формирование коммуникативных действий: } \\
\text { налаживание познавательных контактов со } \\
\text { взрослым, выходящих за рамки конкретной } \\
\text { ситуации; налаживание внеситуативного делово- } \\
\text { го сотрудничества и познавательных контактов с } \\
\text { ровесниками; выполнение правил и норм } \\
\text { поведения }\end{array}$ \\
\hline & $\begin{array}{l}\text { Формы совместной деятельности взрослого и } \\
\text { детей / дошкольников и сверстников: группо- } \\
\text { вое и подгрупповое взаимодействие и индиви- } \\
\text { дуальная деятельность ребенка }\end{array}$ & $\begin{array}{l}\text { Формирование регулятивных действий: планирова- } \\
\text { ние деятельности; стремление довести начатое дело } \\
\text { до конца, получить творческий результат; соблюде- } \\
\text { ние очередности в осуществлении действий } \\
\text { Формирование личностных действий: выбор } \\
\text { наглядных и вербальных средств; творческих } \\
\text { приемов; способов конструктивного общения в } \\
\text { кооперативно-соревновательном взаимодействии со } \\
\text { сверстниками, выражение своих мыслей и чувств }\end{array}$ \\
\hline
\end{tabular}

Учитывая особенности развития речевого творчества у старших дошкольников, взрослый предлагает детям освоить те модули, которые соответствуют их возможностям. В этом случае дошкольники переживают ситуацию успеха. Затем взрослый выбирает различные «линии амплификации развития» для каждого ребенка [14].

Образовательные ресурсы модулей развития речевого творчества детей ориентированы на разные достижения старших дошкольников с учетом собственных желаний и интересов ребенка. Вместе с тем вариативный модуль сохраняет в себе черты инвариативного модуля, а творческий модуль - вариативного и инвариативного модуля одновременно, что очень важно для оптимизации работы с группой детей, имеющих разные результаты развития речевого творчества.

Освоение модулей детьми сопровождается тем, что взрослый отслеживает динамику развития дошкольника, которая отражается в индивидуальной карте развития речевого творчества. Сравнительный анализ результатов педагогического мониторинга позволяет оценить качество педагогического влияния на развитие каждого ребенка, общую картину эффективности образовательной работы с детьми группы. 
Кривоногова О. А. Особенности использования модульного подхода...

Таблица 5

Целесодержательный и технологический компоненты творческого модуля развития речевого творчества детей

\begin{tabular}{|c|c|c|}
\hline $\begin{array}{c}\text { Модуль / } \\
\text { тип СД }\end{array}$ & $\begin{array}{c}\text { Технологическое сопровождение } \\
\text { развития речевого творчества } \\
\text { детей } \\
\end{array}$ & Целесодержательный аспект развития речевого творчества \\
\hline \multirow{4}{*}{$\begin{array}{l}\text { Творче- } \\
\text { ский / } \\
\text { развиваю- } \\
\text { щий }\end{array}$} & $\begin{array}{l}\text { Исследовательский метод. } \\
\text { Способы: диалог на личностные } \\
\text { темы, самодеятельная игра }\end{array}$ & $\begin{array}{l}\text { Формирование интеллектуальных действий (сочинение и } \\
\text { рассказывание сказки по замыслу) }\end{array}$ \\
\hline & $\begin{array}{l}\text { Наглядные и вербальные средст- } \\
\text { ва по выбору участников обще- } \\
\text { ния и игры }\end{array}$ & $\begin{array}{l}\text { Формирование коммуникативных действий: налаживание } \\
\text { личностных контактов со взрослым, выходящих за рамки } \\
\text { конкретной ситуации; налаживание внеситуативного } \\
\text { делового сотрудничества, познавательных и личностных } \\
\text { контактов с ровесниками в соответствии с правилами и } \\
\text { нормами поведения }\end{array}$ \\
\hline & & $\begin{array}{l}\text { Формирование регулятивных действий: планирование и } \\
\text { контроль деятельности в соответствии с поставленной } \\
\text { задачей }\end{array}$ \\
\hline & $\begin{array}{l}\text { Формы деятельности по выбору } \\
\text { участников общения и игры }\end{array}$ & $\begin{array}{l}\text { Формирование личностных действий: выбор средств для } \\
\text { реализации действий, замысла сказки и творческих прие- } \\
\text { мов, способов коммуникативных действий, участников } \\
\text { совместной деятельности и общения; выражение своих } \\
\text { мыслей и чувств }\end{array}$ \\
\hline
\end{tabular}

В контексте развития речевого творчества детей модульный подход дает возможность синтезировать научно-педагогическое знание, заложенное в Федеральном государственном образовательном стандарте дошкольного образования [3]. Предложенная модульная модель аккумулирует в себе педагогические способы организации процесса развития речевого творчества у старших дошкольников с учетом современных требований дошкольного образования (рисунок).

Апробация модульной модели развития речевого творчества у детей осуществлялась в 2016-2017 гг. с личным участием автора. Старшим дошкольникам (42 респондентам) детского сада № 63 (34) г. Томска были предложены игровые ситуации, которые предъявлялись последовательно: от инвариативного до творческого модуля. Игровое взаимодействие предполагало реализацию разных типов СД участников игры, которые оказывались в позициях «руководитель-подчиненный», «ведущий-соисполнитель», «организаторыучастники-партнеры». В ходе игровых ситуаций были установлены дефициты в сформированности интеллектуальных, коммуникативных, регулятивных и личностных действий детей (рисунок).

Инвариативный модуль развития речевого творчества детей. Дети составили неполную/полную модель классической сказки с нарушением ее композиции, перечисляли действия персонажей или пересказывали сюжет, в котором прослеживалась непоследовательность содержательных связей; выражали общепринятое отношение к действиям героев словами «он хороший/плохой», не аргументировали свою оценку. Ролевые диалоги детей требовали руководства. В игровом взаимодействии со сверстниками проявлялась нерешительность дошкольников или дети занимали позицию наблюдателей. Дети испытывали затруднения в следовании порядку игровых действий. Дошкольники не использовали конвенциональные символы или выбор сюжетных картинок не всегда соответствовал правильному решению задачи. В рассказах детей редко встречались сказочные обороты и выражения. 


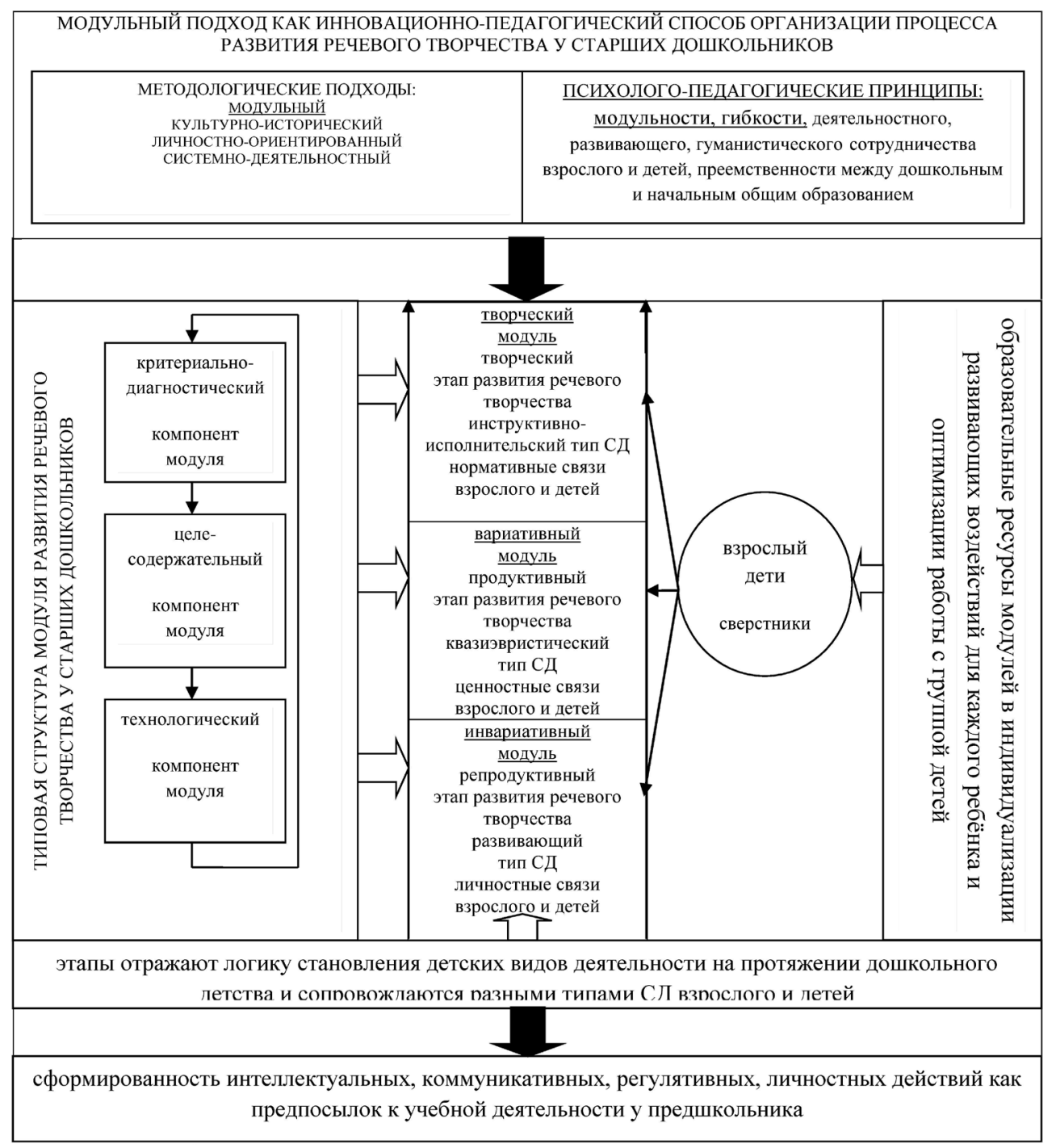

Модульная модель развития речевого творчества у старших дошкольников

Вариативный модуль развития речевого творчества детей. В сочинении коллективного детского рассказа на заданную тему многие дети пересказывали сказку, описывали события не по порядку разложенных картинок и не в соответствии с предложенным замыслом с опорой на оригинальные модели (изображения литературных произведений и современных мультфильмов). Во взаимодействии со сверстниками «лидеры» рассказывали истории за ровесников, если они затруднялись в изложении своих мыслей. Дошкольники нарушали правила игры (перебивали сверстников) и контролировали действия ровесников («теперь твоя очередь» и др.). Аргументация общепринятой оценки действий персонажей сказки уже сопровождалась использованием союза «потому что», конвенциональных и многоплановых символов (как у сверстников). В совместном обсуждении нетрадиционных вариантов развития сказки дошкольники были скованы и лишь некоторые дети задавали вопрос «Почему так?», чаще «А что было дальше?» другим игрокам, т. е. ожидали готовых ответов. Постепенно дошкольники самостоятельно (без напоминания) определяли порядок игровых действий, как правило, по считалке. Сказки детей были бедными по языковым средствам выразительности. Дети стеснялись выражать свое мнение в обсуждении хода и результатов совместной игры. 
Творческий модуль развития речевого творчества детей. Выбор детьми способов коммуникативных действий был в пользу моноигры и совместной деятельности с 2-3 сверстниками-друзьями. Остальные дети занимали позицию наблюдателей. Взрослый не рассматривался как соавтор сказки. Дети не обсуждали с ровесниками тему будущего рассказа, но использовали уже известный конструктивный способ (по считалке) в договоре со сверстниками о порядке игровых действий. В ходе повествования сказки дошкольники напоминали ровесникам правила игры, ориентируясь на символы, и придерживались своего видения продолжения истории. Сказочные модели и сочинения воспроизводили знакомые сюжеты в разных комбинациях. В индивидуальной игре дети сочинили интересные сюжеты, подчиненные единому замыслу, которые не были адресованы сверстникам. В детских сказках появились субъективно значимые события, но были нарушены логические связи, редко встречались диалоги, языковые средства выразительности. Отмечалась скупость и закрытость в выражении дошкольниками своих мыслей и чувств с опорой на разные символы.

Вероятно, проблемы в детском развитии возникли по причине того, что в течение 20132016 гг. педагоги занимали позицию руководителей, работая по готовым конспектам, а детям отводилась роль исполнителей. Подтверждением тому служит нарастающий процент дефицитов в сформированности у детей коммуникативных и личностных действий, когда им предоставлялась возможность проявить инициативу и самостоятельность во взаимодействии с игроками. Вместе с тем образовательный потенциал модулей развития речевого творчества у детей был явным. Дошкольники признавали, что увлекательнее играть в квазиэвристическом или развивающем типе СД, в условиях которой они смогли продемонстрировать свои первые достижения. В дальнейшем в процессе освоения детьми модулей были учтены особенности развития и интересы дошкольников с разными возможностями. Успехи, которых достигли дошкольники, показали положительную динамику (табл. 6).

Таблица 6

Количество детей с дефицитами в развитии в процентном соотношении

\begin{tabular}{|c|c|c|c|c|c|c|c|c|}
\hline \multirow{3}{*}{ Модуль / тип СД } & \multicolumn{8}{|c|}{ Дефициты в детском развитии } \\
\hline & \multicolumn{2}{|c|}{$\begin{array}{c}\text { Интеллектуальные } \\
\text { действия }\end{array}$} & \multicolumn{2}{|c|}{$\begin{array}{c}\text { Коммуникативные } \\
\text { действия }\end{array}$} & \multicolumn{2}{|c|}{$\begin{array}{c}\text { Регулятивные } \\
\text { действия }\end{array}$} & \multicolumn{2}{|c|}{$\begin{array}{c}\text { Личностные } \\
\text { действия }\end{array}$} \\
\hline & ИС & $\mathrm{OM}$ & ИС & $\mathrm{OM}$ & ИС & $\mathrm{OM}$ & ИС & $\mathrm{OM}$ \\
\hline $\begin{array}{l}\text { Инвариативный / } \\
\text { инструктивно-исполни- } \\
\text { тельский }\end{array}$ & $\begin{array}{c}69 \% \\
\text { (29 чел.) }\end{array}$ & $\begin{array}{c}28 \% \\
\text { (12 чел.) }\end{array}$ & $\begin{array}{c}81 \% \\
\text { (34 чел.) }\end{array}$ & $\begin{array}{c}31 \% \\
(13 \text { чел.) }\end{array}$ & $\begin{array}{c}24 \% \\
(10 \text { чел.) }\end{array}$ & $\begin{array}{c}21 \% \\
\text { (9 чел.) }\end{array}$ & $\begin{array}{c}83 \% \\
\text { (35 чел.) }\end{array}$ & $\begin{array}{c}26 \% \\
(11 \text { чел.) }\end{array}$ \\
\hline $\begin{array}{l}\text { Вариативный / } \\
\text { квазиэвристический }\end{array}$ & $\begin{array}{c}83 \% \\
\text { (35 чел.) }\end{array}$ & & $\begin{array}{c}88 \% \\
\text { (37 чел.) }\end{array}$ & & $\begin{array}{c}62 \% \\
\text { (26 чел.) } \\
\end{array}$ & & $\begin{array}{c}81 \% \\
\text { (34 чел.) }\end{array}$ & \\
\hline $\begin{array}{l}\text { Творческий / } \\
\text { развивающий }\end{array}$ & $\begin{array}{c}76 \% \\
\text { (32 чел.) }\end{array}$ & & $\begin{array}{c}90 \% \\
\text { (38 чел.) }\end{array}$ & & $\begin{array}{c}52 \% \\
(22 \text { чел.) }\end{array}$ & & $\begin{array}{c}88 \% \\
(37 \text { чел.) }\end{array}$ & \\
\hline
\end{tabular}

Примечание. ОС - игровые ситуации; ОМ - освоение модулей.

Интеллектуальныле действия детей. Затруднений с построением модели и пересказом классической сказки у детей уже не возникало. В выражении общепринятого отношения к поступкам героев сказки дошкольники ориентировались на сюжетные картинки и конвенциональные символы. В высказываниях появилась аргументация оценки действий персонажей, но некоторые дети продолжали просто констатировать факты («Баба-яга злая» и др.). Дошкольники использовали различные приемы экспериментирования в построении модели сказки по замыслу, отдавали предпочтение придумыванию концовки фольклорного сюжета, совмещали событийные и смысловые темы в оригинальных историях, включали в сочинения реальных людей (свадьба и счастливая семейная жизнь и др.). Сюжеты рассказов были близки детям (прогулка с родителями и др.), в ходе их повествования дошкольники рассу- 
ждали, использовали союзы «потому что», «поэтому». Выражая субъективное и аргументированное мнение о действиях героев, многие дети отходили от стереотипных представлений в их восприятии, но использовали символы с конкретным культурным контекстом. В своих рассказах дошкольники использовали языковые средства выразительности.

Коммуникативные действия детей. Налаживание детьми деловых контактов с участниками игры было успешным. Познавательные контакты дошкольников с игроками отличались обменом вариантов развития сюжетов, но не все дети самостоятельно задавали вопросы участникам игры. В решении коммуникативных и организационных проблем дети высказывали конструктивные и вариативные идеи. Постепенно дети стали делиться своими планами, намерениями, замыслами, интересовались мыслями и чувствами игроков. Дети договаривались об общем с ровесниками замысле сказки, но иногда не придерживались единой содержательно-идейной линии. Отмечались случаи нарушения детьми правил игры: торопили сверстников. Соревновательные отношения детей проявлялись в интересе «У кого сказка получилась лучше?». В свободной деятельности они объединялись в игру по симпатиям. Специально организованные ситуации помогли им осознать, что игра может разворачиваться не только с друзьями, нужно помогать, по-деловому объяснять правила игры ровесникам. Значительно сократилось количество выборов детей в пользу индивидуальной игры для себя.

Регулятивные действия детей. Во взаимодействии с игроками дети сохраняли цель деятельности, вносили в нее коррективы под руководством участников игры. К замечаниям ровесников дошкольники относились более серьезно, так как все чаще оказывались в роли «умельцев». Планирование деятельности получалось не у всех дошкольников: замысел истории или не был заранее продуман или менялся первоначальный сказочный смысл по ходу развития событий. В самодеятельной игре дети рассказывали классические сказки с небольшими отступлениями от фольклорных историй. Для большинства детей было характерно ступенчатое планирование сюжета. Во взаимодействии с ровесниками дети уточняли, соблюдали, контролировали очередность действий. В обсуждении хода и результатов совместной деятельности дошкольники высказывали свои суждения относительно того, получилась ли сказка «складной».

Личностные действия детей. В реализации замысла дети субъективно интерпретировали сказочные факты. В игровом взаимодействии дети применяли разные наглядные средства. Детские сказки стали более разнообразными по языковым средствам выразительности. В обсуждении действий персонажей, процесса и итогов совместной деятельности дошкольники использовали вариативные речевые конструкции-рассуждения. Значительно расширился диапазон применяемых детьми творческих приемов, культурных способов и форм взаимодействия с участниками игры. Событийные и смысловые темы сказок раскрывали личностно значимые для детей сюжеты. В детских игровых объединениях участвовали ровесники с разными возможностями и достижениями. Теперь взрослый воспринимался детьми не как контролер, а как соавтор общего замысла. Дошкольники приобрели свободу в выражении своих мыслей и чувств.

В целом апробация модульной модели формирования речетворческой деятельности у старших дошкольников в детском саду прошла успешно. Эксперимент подтвердил предположение о том, что использование модульной модели развития речевого творчества детей является эффективным в формировании интеллектуальных, коммуникативных, регулятивных и личностных действий у старших дошкольников как предпосылок к учебной деятельности на этапе завершения ими дошкольного образования.

\section{Список литературы}

1. Ворошнина Л. В. Обучение творческому рассказыванию // Дошкольное воспитание. 1991. № 2. С. 2-10.

2. Краснова В. А. Формирование способности к речевому творчеству у старших дошкольников: на материале сказок: дис. ... канд. пед. наук. М., 1999. 182 с. 
3. Федеральный государственный образовательный стандарт дошкольного образования // Российская газета. 25.11.2013. № 6241. С. 18-20.

4. Юцявичене П. А. Теоретические основы модульного обучения: дис. ... д-ра пед. наук. Вильнюс, 1990. 437 с.

5. Кудрявцев В. Т. Психология развития человека: основания культурно-исторического подхода. Рига: Эксперимент, 1999. $160 \mathrm{c}$.

6. Никитина Л. А., Поздеева С. И. Педагогическое наследие Г. Н. Прозументовой как ориентир для науки и образовательной практики // Научно-педагогическое обозрение (Pedagogical Review). 2015. Вып. 4 (10). С. 7-14.

7. Поздеева С. И. Типология уроков в концепции педагогики совместной деятельности // Научно-педагогическое обозрение (Pedagogical Review). 2016. Вып. 3 (13). С. 36-41.

8. Ковалева Т. М. Организация тьюторской деятельности в современной школе // Проблемы современного образования. 2010. № 4. С. 19-23.

9. Психология одаренности детей и подростков / под ред. Н. С. Лейтес. М.: Академия, 1996. 416 с.

10. Развитие общения дошкольников со сверстниками / под. ред. А. Г. Рузской. М.: Педагогика, 1989. 216 с.

11. Смирнова Е. О. Особенности общения с дошкольниками: учеб. пособие для студ. сред. пед. учеб. заведений. М.: Академия, 2000. 160 с.

12. Трифонова Е. В. Проблема самодеятельной игры в контексте основных идей А. В. Запорожца // Культурноисторическая психология. 2006. № 1. С. 77-83.

13. Киселёва О. И., Кривоногова О. А. Реализация адаптивной образовательной деятельности по формированию речевого творчества старших дошкольников с учетом особенностей их развития // Вестн. Томского гос. пед. ун-та (TSPU Bulletin). 2015. Вып. 1 (153). С. 80-86.

14. Лыкова И. А. Индивидуальный маршрут развития ребенка в проектной деятельности // Детский сад: теория и практика. 2012. № 9. С. 80-87.

Кривоногова Ольга Анатольевна, методист, Детская организация раннего развития «Ладушки» (ул. С. Лазо, 6/2, Томск, Россия, 634063). E-mail: koa1979@inbox.ru

Материал поступил в редакиџию 22.01.2020.

\section{DOI 10.23951/2307-6127-2020-2-220-232}

\section{PECULIARITIES OF USING MODULES FOR DEVELOPING SPEECH CREATIVITY OF SENIOR PRESCHOOLERS IN A KINDERGARTEN}

\section{O. A. Krivonogova}

Autonomous noncommercial organization of early development "Ladushki", Tomsk, Russian Federation

Changes concerning reforming preschool education in Russia at the end of the XX century and the beginning of the XXI century determined the inner of the notion "speech creativity" as well as theoretical and methodological approaches to developing children's speech and speech creativity. At the end of the XX century the notion "speech creativity" is associated with the child's artistic and creative activities; different scientific ideas about the development of children's speech creativity are formed. Organizing the process of developing preschoolers' speech creativity in accordance with ideology of the new standard of preschool education requires a basic idea of pedagogical ways of organizing children's artistic and creative activities by means of a fairy-tale. In connection with it, using modules as the innovative organizational pedagogical basis for developing children's speech creativity in accordance with the main conceptual ideas of the educational standard becomes essential. At the beginning of making up modules there established typical relations between reproductive, productive and creative stages of developing senior preschoolers' speech creativity that reflect the logic of the emergence of children's activities during the period of preschool childhood and are followed by different types of mutual activities of the adult and children with the purpose to obtain developing and humanistic relationships between the participants of the 
interaction. Educational resources of modules are compiled to reveal and enrich the subjective experience of children with reference to their interests and capabilities. The effectiveness of using modules at developing children's speech creativity in a preschool educational institution is proved by successful increase of children's capacity for learning activities.

Keywords: speech creativity, senior preschoolers, module approach, module model, conditions of developing universal learning operations.

\section{References}

1. Voroshina L. V. Obucheniye tvorcheskomu vyskazyvaniyu [Teaching creative telling]. Doshkol'noye obrazovaniye-Preschool Education, 1991, no. 2, pp. 2-10 (in Russian).

2. Krasnova V. A. Formirovaniye sposobnosti k rechevomy tvorchestvu u starshikh doshkol'nikov: na materiale skazok. Dis. kand. ped. nauk [Developing a capability of speech creativity with senior preschoolers: using fairy-tales. Dis. cand. ped. sci.]. Moscow, 1999. 182 p. (in Russian).

3. Federal'nyy gosudarstvennyy obrazovatel'nyy standart doshkol'nogo obrazovaniya [Federal State Educational Standard of Preschool Education]. Rossiyskaya gazeta, 25 November, 2013, no. 6241, pp. 18-20 (in Russian).

4. Yutsyavichene P. A. Teoreticheskye osnovy modul'nogo obucheniya. Dis. d-ra ped. nauk [Theoretical basics of module teaching. Dis. doct. ped. sci.]. Vilnius, 1990. 437 p. (in Russian).

5. Kudryavtsev V. T. Psikhologiya razvitiya cheloveka: osnovaniya kul turno-istoricheskogo podkhoda [Psychology of developing a person: basic ideas of cultural and historical approach]. Riga, Eksperiment Publ., 1999. 160 p. (in Russian).

6. Nikitina L. A, Pozdeyeva S. I. Pedagogicheskoye naslediye G. N. Prozumenovoy kak orientir dlya pedagogicheskoi nauki i praktiki [The padgogical heritage of G. N. Prozumentova as a benchmark for science and educational practice]. Nauchnopedagogicheskoye obozreniye - Pedagogical Review, 2015, vol. 4 (10), pp. 7-14 (in Russian).

7. Pozdeyeva S. I. Tipologiya urokov v konsteptsii pedagogiki sovmestnoi deyatel'nosti [Type lessons in the concept joint activity pedagogy]. Nauchnopedagogicheskoye obozreniye - Pedagogical Review, 2016, vol. 3 (13), pp. 3641 (in Russian).

8. Kovaleva T. M. Organizatsiya t'utorskoy deyatel'nosti v sovremennoy shkole [Organizing tutor activities in a contemporary school]. Problemy sovremennogo obrazovaniya - Problems of modern education, 2010, no. 4, pp. 19-23 (in Russian).

9. Psikhologiya odaryonnosti detey i podrostkov [Psychology of gifted children and teenagers]. Ed. by N. S. Leytes. Moscow, Akademiya Publ., 1996. 416 p. (in Russian).

10. Razvitiye obscheniya deshkol'nikov so sverstnikami [The development of preschoolers' communication with peers]. Ed. by A. G. Ruzskaya. Moscow, Pedagogika Publ., 1989. 216 p. (in Russian).

11. Smirnova E. O. Osobennosti obscheniya s doshkol'nikami: uchebnoye posobiye dlya studentov srednespetsial'nykh pedagogicheskikh uchebnykh zavedeniy [Peculiarities of communicating with preschoolers: a manual for students of secondary pedagogical institutions]. Moscow, Akademiya Publ., 2000. 160 p. (in Russian).

12. Trifonova E. V. Problema samodeyatel'noy igry v kontekste osnovnykh idey A.V. Zaporozhtsa [The Problem of an independently organized game from the point of view of A.V. Zaporozhets]. Kul turnoistoricheskaya psikhologiya-Cultural-Historical Psychology, 2006, no. 1, pp. 77-83 (in Russian).

13. Kiseleva O. I., Krivonogova O.I. Realizatsiya adaptivnoy obrazovatel'noy deyatel'nosti po formirovaniyu rechevogo tvorchestva starshikh doshkol'nikov s uchetom osobennostei ikh razvitiya [The realization of the adaptive educational activity for the speech creation forming of the preschool age children taking into account the features of their development]. Vestnik Tomskogo gosudarstvennogo pedagogicheskogo universiteta - TSPU Bulletin, 2015, vol. 1 (153), pp. 80-86 (in Russian).

14. Lykova I. A. Individual'nyy marshrut razvitiya rebyonka v proektnoy deyatel'nosti [The individual route of the child's development in project activities]. Detskiy sad: Teoriya i praktika, 2012, no. 9, pp. 80-87 (in Russian).

Krivonogova O. A., Autonomous noncommercial organization of early development "Ladushki" (ul. S. Lazo, 6/2, Tomsk, Russian Federation, 634063). E-mail: koa1979@inbox.ru 